\title{
Effectiveness of GeoGebra in teaching school mathematics ${ }^{1}$
}

\author{
Bir Bahadur Chalaune and Abatar Subedi
}

\begin{abstract}
This article aims to explain the effectiveness of using Information and Communication Technology (ICT) in teaching and learning school mathematics. The paper is based on the results of one month experiment of GeoGebra software in teaching and learning the concepts and problems included in the chapter of mensuration of secondary level mathematics. The effectiveness of using ICT tools were explored by measuring achievement level with the help of achievement test and overall perceptions of using ICT tools through questionnaire. The data were analyzed and interpreted by using table, frequency, percentage, mean, SD and t-test. The findings revealed that there was high mean score in achievement in mathematics of experimental group (teaching with ICT) than that of control group (without using ICT), and the difference was significant at 0.05 level. Likewise, the students of experimental group had positive perception to support the use of ICT tools in teaching and learning mathematics. Thus, the use of ICT, particularly GeoGebra is an effective tool to increase achievement; to promote curiosity, creativity; to make clear sense of concepts; and to encourage overall learning of students in mathematics. Finally, the study suggests that school mathematics teachers need to use ICT for effective teaching and learning.
\end{abstract}

Keywords: Achievement; GeoGebra; Mensuration; Perception; School mathematic

\footnotetext{
${ }^{1}$ Cite this article as: Chalaune, B.B. and Subedi, A. (2020). Contemporary Research: An Interdisciplinary Academic Journal, vol. 4 (1)

Bir Bahadur Chalaune/ Abatar Subedi: Master's student/ Lecturer, Mathematics Education, Tribhuvan University, Nepal Email: veer536618@gmail.com

Article history: Received on July 11; Accepted on October 10; Published on October 30 Peer reviewed under the authority of CRAIAJ, academic journal of Ghodaghodi Multiple Campus, Kailali, Nepal, with ISSN 2717-4611 (Print) and ISSN 2717-462X (Online).

(C) 2020 CRAIAJ
}

Full text of this article can be downloaded from www.craiaj.com and www.nepjol.info 


\section{Introduction}

Using Information and Communication Technology (ICT) in teaching and learning is the worldwide concern, particularly in school mathematics. Information and Communication Technologies is rapidly spreading its area in developed and developing countries. It directly effects in many fields including mathematics education. Keong, Horani and Daniel (2005) have explained, "the use of ICT in teaching can make the teaching process more effective and enhance the student's capabilities in understanding basic concepts" (p. 50). The teacher no longer has to give pupils work sheets like ransom notes. The use of ICT is rapidly increasing in Nepal from last decade. In education sector, as the place of mathematics, ICT plays visualization role for all levels. Ms-Word, Ms-Power Point, Spread sheet, MeDase CLASS, MOODLE, GeoGebra, Mathematica, MATLAB, different educational pages, and links are popular to the teachers and students. Among them GeoGebra is mostly useful and effective according to present context of Nepal in different area of mathematics. At first, GeoGebra software was developed by Markus Honewarter in 2001/2002 and then the use of it is increasing day by day in the field of teaching and learning. Now, the use of ICTs, particularly the use of GeoGebra software is becoming a most effective tool for teaching and learning mathematics. GeoGebra is an interactive tool which can be used in teaching and learning of several areas of mathematics including geometry, algebra, statistics and calculus application, and it is intended for learning and teaching mathematics and science from primary school to university level (Majerek, 2014). This is freely available software from www.geogebra.org with various GeoGebra applets. Millions of users are connecting everyday through online. We can also access this software offline.

Government of Nepal, Ministry of Education, through National Curriculum Framework (NCF), has introduced ICT as a subject as well as a tool for instruction in school education. Some universities/colleges and schools have already started ICT as a separate subject as well as a means of teaching learning process (ICT Master Plan, 2013). Bozkurt \& Ruthven (2009) emphasized that the stage teachers were at in terms of learning to teach with this software indicated differences in regard to establishing a functioning resource system especially in teaching the operation of the software, preparing the dynamic files and the choice of tasks. It shows that the most experienced teacher forever more fluent in managing his/her system of resources for

Full text of this article can be downloaded from www.craiaj.com and www.nepjol.info 
teaching and learning mathematics at school level. This study was intended to find the effectiveness of GeoGebra in teaching and learning mathematics and to analyze the students' perceptions towards the use of GeoGebra software.

\section{Literature review}

There are several literatures which emphasize the importance of using ICT tools in teaching and learning mathematics. In this sense the research of Sah (2017) showed that teachers have positive attitude towards using media tools in their classroom teaching. Keong, Horani\& Daniel (2005) pointed that using ICT in teaching learning enhances motivation making the concepts clear and meaningful in any subject matter. Similarly, using internet as teaching learning materials is a prime source of knowledge. Subedi (2017) explained that the use of authentic materials in teaching learning mathematics is a questionable because there are priorities in using shadow learning materials and students learning are only based on teachers note and lecture. This type of issue can be solved by using various ICT tools such as internet, mobile, and other mathematical software in addition to daily using learning resources in mathematics. Also, Prabha \& Shanavas (2014) worked together an article that "Implementation of E-Learning Package for mensuration-A Branch of Mathematics" defining e-learning ideas specially FLIP classroom learning in India. They described in their paper, ideas of FLIP model in mensuration standing on the curriculum of grade 6 to 10 of Tamil Nadu state. Finally they had reached that the teacher plays a major role in defining problems and solution steps in word problems with multiple steps problems.

Similarly, the research of Barai (2017) on "perception of students on the use of GeoGebra in teaching school geometry" has concluded that students had positive perception towards using GeoGebra. Lamichhane (2017) pointed that students taught by using GeoGebra perform better performance than traditional teaching/learning approach in mathematics. Likewise, Saha, Ayub \& Tarmiz (2010), mentioned that the use of GeoGebra enhanced the students' performance in learning coordinate Geometry at school level. The findings of their study showed that computer assisted learning like using GeoGebra help students to increase achievement in mathematics than only using traditional approaches of learning by using paper-pencil. The article of Majerek (2014) on "Application of GeoGebra for teaching Mathematics" declared that GeoGebra has placed on the best position in present technology for teaching

Full text of this article can be downloaded from www.craiaj.com and www.nepjol.info 
mathematics among six significant principles of mathematics education stated by National Council for Teaching Mathematics (NCTM).

The above literatures reflected that GeoGebra is becoming a popular and useful tool for teaching and learning mathematics from school to higher education due to its importance in visualizing and conceptualizing mathematical concepts. From the conceptualization of these literatures, it is also expected that GeoGebra can display the geometric and algebraic views of the solution for any mathematical problems that help students to understand relations of several mathematical concepts. That is why, this study intends to measure and experience the further effectiveness of GeoGebra in teaching and learning school mathematics, particularly the concept "mensuration".

\section{Conceptual framework}

On the basis of empirical and theoretical literatures that were reviewed in earlier section, the following conceptual framework was constructed. This framework was used to teach mathematics concepts which were planned to implement GeoGebra software in experimental group of this study.

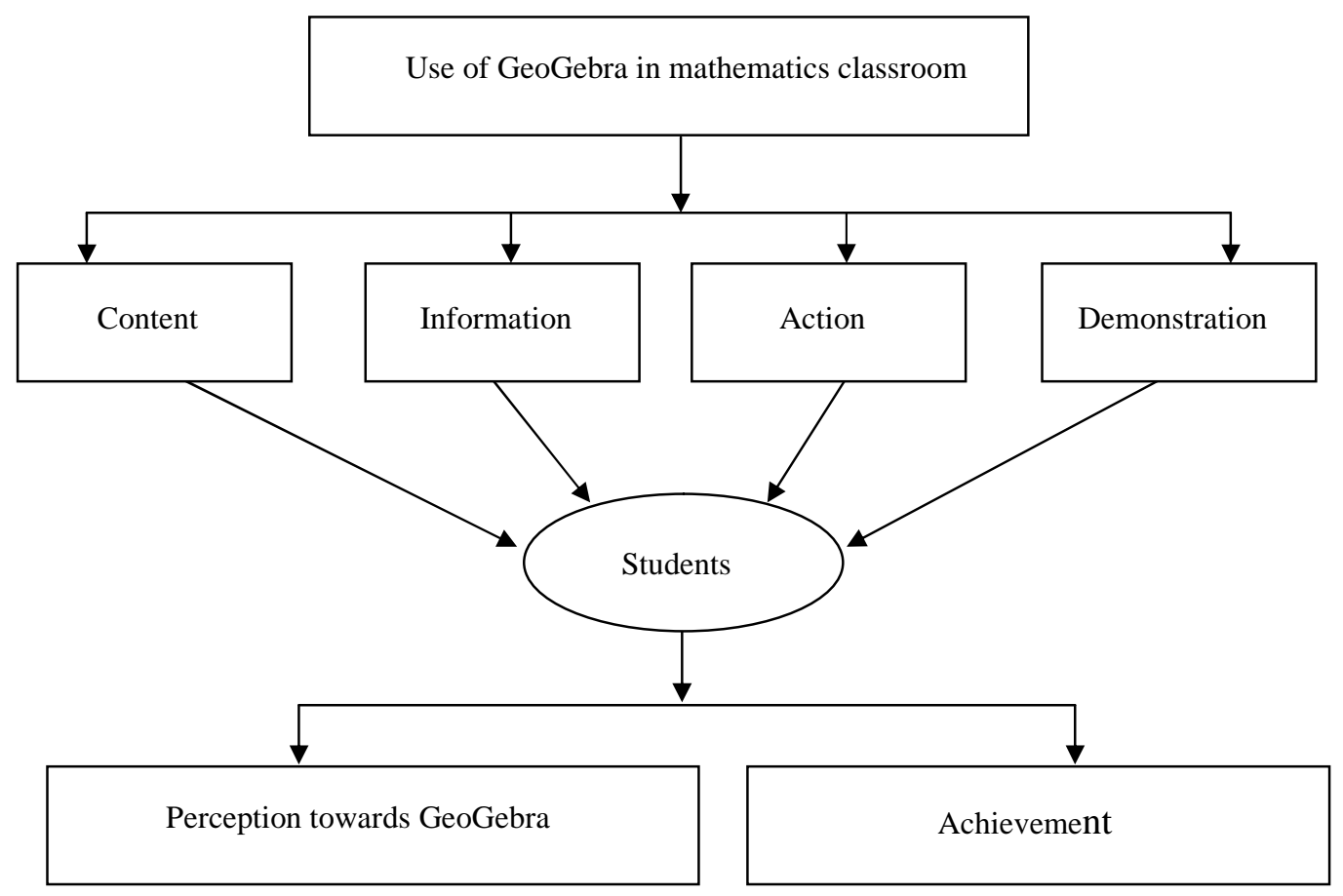

Full text of this article can be downloaded from www.craiaj.com and www.nepjol.info 
According to this conceptual framework, teacher/researcher taught at first by using GeoGebra software within one-month duration in experimental group where teaching was concerned about contents, information, actions and demonstrations activities to students learning. Researcher/teacher motivated the students during the use of GeoGebra in teaching mathematics. Finally, the achievement test was conducted from the contents which were taught by using GeoGebra in experimental group and students' perception towards using GeoGebra was measured.

\section{Methods}

This was an experimental research on which pre-test post-test non-equivalent control group design was applied to examine the effectiveness of the GeoGebra software in teaching and learning mathematics at secondary level. For two secondary schools and its grade ten students were selected by using convenience sampling techniques where experimental and control group were chosen by tossing coin. The experimental group was taught by using the GeoGebra in the content mensuration during one month and the same contents for the same time in control group were delivered by using traditional method of teaching. These groups were treated equally as much as possible in all aspects to control the external and internal validity threats and to ensure the effect of treatment in experimental group. The same achievement tests were used for both groups in pre-test and post-test which were finalized after piloting and validating from the experts. However, the pre-test and post-test questions were different. Moreover, the questionnaires were prepared in Likert scale with five alternatives: strongly agree, agree, neutral, disagree and strongly disagree, to measure the perception of using GeoGebra in teaching mathematics for the students of experimental group. Finally, the obtained data were analyzed and interpreted by using the descriptive statistics such as table, frequency, percentage, mean, standard deviation, and the inferential statistics t-test, at 0.05 levels of significances. The obtained data were analyzed and interpreted in the several heading as described below and discussed the findings with the previous theoretical and empirical literatures.

\section{Analysis}

\section{Analysis of mean achievement scores on pre-test}

The pre-test was taken to analyze the achievement level of grade $\mathrm{X}$ students in mathematics before experiment. Based on students learned concepts from curriculum 
of grade IX and basic concepts of mensuration, the pre-test was constructed which had only eleven subjective items. This test was administered in both experimental and control groups. Table 1 shows the mean and standard deviation of achievement test of pre-test and their corresponding t-value.

Table 1: Mean and standard deviation of pre-test

\begin{tabular}{|l|c|c|c|c|c|}
\hline Groups & $\mathrm{N}$ & Mean & SD & $\mathrm{t}$ & Significant (2-tailed) \\
\cline { 1 - 3 } Experimental & 27 & 7.37 & 4.24 & \multirow{2}{*}{1.639} & 0.11 \\
\hline Control & 21 & 9.71 & 5.38 & & \\
\hline
\end{tabular}

$t$-value significant at $\mathrm{p}<0.05$

The above table shows that the mean achievement score of control group was greater than that of experimental group in mathematics by 2.34. Similarly, the result indicates that the control group had higher standard deviation than that of experimental group by 1.14 . The calculated t-value at $5 \%$ level of significance is 1.639 and corresponding two tailed p-value is 0.11 as shown in above table. However, this difference was not significant because its p-value 0.11 is greater than 0.05.It means that the control group and experimental groups are not different in terms of mean achievement score in mathematics on the basis of pre-test results. That is both groups seem similar in mathematics achievement.

After the analysis of achievements results of both groups on pre-test, I drew a lottery method with the help of coordinator teacher of one school to define the experimental group and the control group. Then, I had started one month teaching on both groups with same contents 'mensuration' of grade X mathematics.

\section{Analysis of mean achievement scores of post-test}

After the analysis of the results on pre-test, the researcher declared experimental and control group by tossing the coin and then begun experiment. The experimental group was taught by using GeoGebra software and the control group was taught by traditional method. Here are some snap shots of GeoGebra applet which was used during my experiment period upon experimental group.

This GeoGebra applet was based on combine figures where questions were asked to

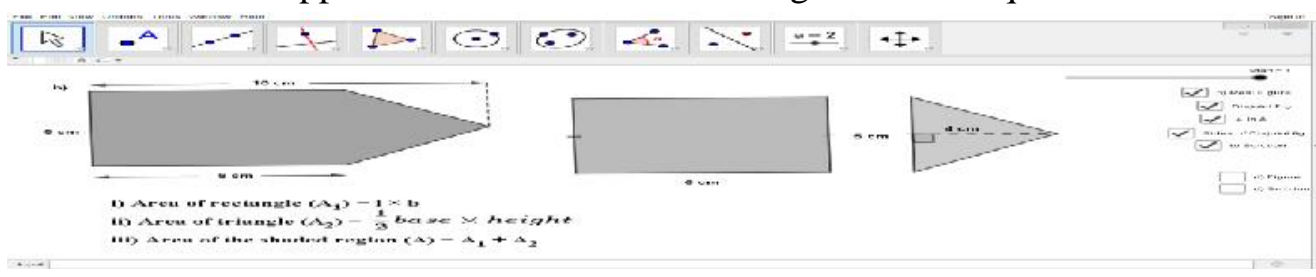

Full text of this article can be downloaded from www.craiaj.com and www.nepjol.info 
calculate its area. The applet has been developed by using slider and first check box. If the slider and check box active, then the combine figure disjoints into two parts as rectangle and triangle. And other check box defines their length, breadth and height. After separating the combine figure and its values, students were clear about its concept and felt comfortable to use formulae for calculating the area of the figure.

The next applet gives the brief information about area of path running outside the rectangle. This applet is based on check box and animated point defining its radio button on and off. While radio button of check box is click one by one, then the inside rectangle, outside rectangle, width, a running point and their definitions are release simultaneously. The picture and proof was given in text book. But students were more cleared about derivation of formula after using given applet.

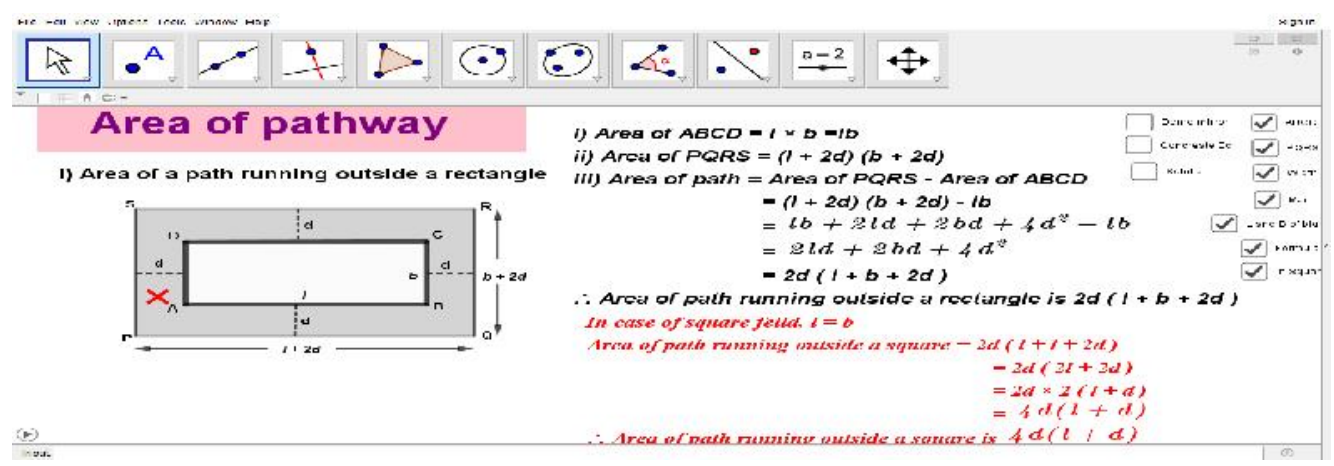

Similarly, the following are the two examples of GeoGebra applets as used in teaching the area of solid figure in experimental group.

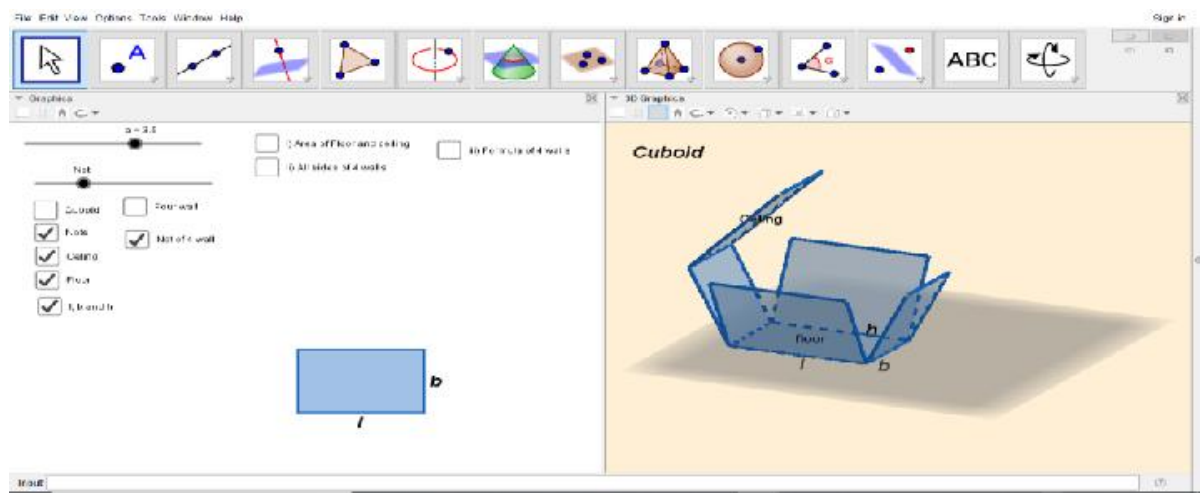

Full text of this article can be downloaded from www.craiaj.com and www.nepjol.info 
The given applet was based on 3D cuboid along its nets which gave clear concept of four wall, ceiling and floor of a room to the students. It also helped to develop the concept of derivation formula to calculate the area of four walls and area of a room by using slider and check boxes. The area of rectangle is length $\times$ breadth mostly helped to derive all the formulae for the walls, ceiling and floor of the room in experimental group.

The applet alongside was developed according to given question in its $3 \mathrm{D}$

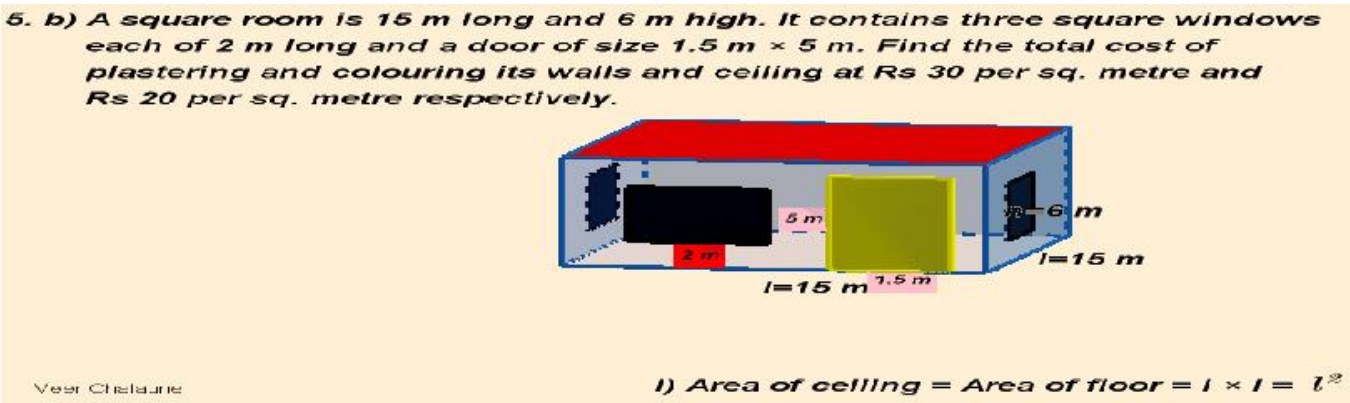

view of GeoGebra. The applet helped the students to understand the question by comparing in their real life as 3D view. One applet was displayed to the students, for the example of a room having three equal windows with same dimensions and a door as well as a room having length, breadth and height. It was experienced that students solved the given problem related to calculate the cost of plastering and coloring the walls of such type of three dimensional shapes easily with the help of 3D applets displayed in GeoGebra.

Thus, it was experienced that the use GeoGebra software in teaching mensuration was effective to learn the mathematical concepts effectively in comparison to the traditional approach of teaching mathematics. The following table explains the mean and standard deviation of the achievement score of post-test result of both experimental and control groups.

Table 2: Mean and standard deviation of post-test

\begin{tabular}{|c|c|c|c|c|c|}
\hline Groups & $\mathrm{N}$ & Mean & $\mathrm{SD}$ & $\mathrm{t}$ & Significant (2-tailed) \\
\hline Experimental & 27 & 23.44 & 5.06 & \multirow{2}{*}{7.23} & 0.000 \\
\hline Control & 21 & 12.81 & 5.05 & & \\
\hline
\end{tabular}

$t$-value significant at $\mathrm{p}<0.05$. 
Table 2 shows that the difference between mean score of the experimental and the control groups is 10.53 , and that of SD is 0.01 . The corresponding t-value is 7.23 at $5 \%$ level of significant. The p-value for 2-tailed test is 0.000 , which is less than 0.05 . This value indicates that the difference in the mean score of the two groups is significant. So, the above result shows that the result of students taught by using GeoGebra software is better than the students taught by traditional method. Hence, this concludes that the students in the experimental group performed higher achievement than the control group. The use of GeoGebra in teaching and learning mathematics at school increases students' achievement score.

\section{Perception of students towards the use of GeoGebra software}

The effectiveness of using GeoGebra in teaching learning school mathematics was also measured by evaluating the perception of students toward using it. The perception was measured with the help of questionnaire which was developed on the basis of Likert five point scales but combined the responses on strongly agree and agree into agree, and strongly disagree and disagree into disagree for the process of analysis. There were seventeen statements of standing on different dimensions of perception in the questionnaire. The questionnaire was distributed to only twenty six students among twenty seven students of experimental group and they were returned back after thirty minutes by attempting their views towards GeoGebra software. The questionnaires included five subheadings as GeoGebra in mathematics, GeoGebra in mensuration, GeoGebra in subject matter of mathematics, and GeoGebra in curriculum. The table 3 displays the students' perception score towards the use of GeoGebra.

Table 3: Perception of students toward GeoGebra software

\begin{tabular}{|l|l|l|l|l|}
\hline SN & Items & $\begin{array}{l}\text { Agree } \\
(\%)\end{array}$ & $\begin{array}{l}\text { Neutral } \\
(\%)\end{array}$ & $\begin{array}{l}\text { Disagree } \\
(\%)\end{array}$ \\
\hline 1. & $\begin{array}{l}\text { I like to learn and study by using GeoGebra software in } \\
\text { mathematics. }\end{array}$ & 96.15 & 3.85 & 0 \\
\hline 2. & $\begin{array}{l}\text { I got clear concept while teacher used GeoGebra in } \\
\text { teaching mathematics. }\end{array}$ & 100 & 0 & 0 \\
\hline 3. & $\begin{array}{l}\text { I feel GeoGebra is essential and important software for } \\
\text { teaching mathematics. }\end{array}$ & 96.2 & 3.8 & 0 \\
\hline 4. & $\begin{array}{l}\text { GeoGebra mostly encourage me and my friends to take } \\
\text { path and improve mathematics performances. }\end{array}$ & 92.3 & 7.7 & 0 \\
\hline
\end{tabular}

Full text of this article can be downloaded from www.craiaj.com and www.nepjol.info 


\begin{tabular}{|c|c|c|c|c|}
\hline 5. & $\begin{array}{l}\text { GeoGebra software made me more clearly about any } \\
\text { figure that visualize through teacher in mensuration. }\end{array}$ & 100 & 0 & 0 \\
\hline 6. & $\begin{array}{l}\text { I like to study mensuration lesson using GeoGebra } \\
\text { software. }\end{array}$ & 96.2 & 3.8 & 0 \\
\hline 7. & $\begin{array}{l}\text { The use of GeoGebra software in mensuraion chapter } \\
\text { ensures long time memorization of what the teacher } \\
\text { taught. }\end{array}$ & 73.1 & 26.9 & 0 \\
\hline 8. & $\begin{array}{l}\text { The GeoGebra software gives as very clear concept about } \\
\text { mensuration connecting on real life problems. }\end{array}$ & 88.5 & 11.5 & 0 \\
\hline 9. & $\begin{array}{l}\text { The software gives us meaningful information on subject } \\
\text { matter. }\end{array}$ & 100 & 0 & 0 \\
\hline 10. & $\begin{array}{l}\text { Using GeoGebra software distracts my concern on subject } \\
\text { matter. }\end{array}$ & 7.7 & 7.7 & 84.6 \\
\hline 11. & $\begin{array}{l}\text { GeoGebra software makes teacher and me very lazy and } \\
\text { careless. }\end{array}$ & 0 & 3.8 & 96.2 \\
\hline 12. & $\begin{array}{l}\text { The environment of class becomes noisy while teacher use } \\
\text { GeoGebra software. }\end{array}$ & 3.8 & 30.8 & 65.4 \\
\hline 13. & $\begin{array}{l}\text { I want to learn this software to make clear concept in } \\
\text { mathematics subject matter as much as possible. }\end{array}$ & 88.5 & 11.5 & 0 \\
\hline 14. & $\begin{array}{l}\text { Every school should use GeoGebra software to teach } \\
\text { mathematics in effective way. }\end{array}$ & 92.3 & 7.7 & 0 \\
\hline 15. & $\begin{array}{l}\text { The curriculum should include GeoGebra software in } \\
\text { computer science subject for further study. }\end{array}$ & 73.1 & 26.9 & 0 \\
\hline 16. & $\begin{array}{l}\text { I will explain about GeoGebra software to all who have } \\
\text { curiosity. }\end{array}$ & 76.9 & 26.1 & 0 \\
\hline
\end{tabular}

\section{Source: Field study}

Results from above table show that, students mostly responded positively toward the use of GeoGebra software in mathematics. The majority of students $(96.15 \%)$ mentioned that they liked to learn and study by using GeoGebra software in mathematics through teacher. All students (100\%) mentioned that GeoGebra helped them to get clear concepts on mathematics, visualize problem of mensuration, and provide meaningful information about subject matter. The majority of students (more than 90\%) agreed that GeoGebra is essential and important software made me more clearly about any figure that visualize through teacher in mensuration for teaching mathematics, mostly encourage students to participate in mathematics problems, increase performances, and can make effective teaching and learning mathematics. 
Almost all students (96.2\%) liked to study mensuration lesson using GeoGebra software. More than $80 \%$ students disagreed with GeoGebra software distracted their concern on subject matter, and it makes teacher and students very lazy and careless. Similarly, majority of students disagreed with environment of class becomes noisy while teacher use GeoGebra software for teaching. The majority of students in experimental group were also perceived that every school should use GeoGebra software to teach mathematics in effective way, and curriculum should include GeoGebra software in computer science subject for further study.

The major findings of this research are discussed here. The first and most important finding of this research was that the students who were taught by using GeoGebra software did get high achievement score than that of students taught by traditional method of teaching in mensuration in school mathematics. Lamichhane (2017) also revealed that students taught by using GeoGebra perform better performance than traditional teaching approach in mathematics. Similarly, the research of Saha, Ayub \& Tarmiz (2010) has supported that the use of GeoGebra enhanced the students' performance in mathematics. It was also experienced that GeoGebra helped students to understand two-dimensional and three-dimensional shapes and geometry figures of mensuration.

The findings equally revealed that the school students had positively perceived the use of GeoGebra in teaching mathematics. According to students' perception, GeoGebra makes teaching and learning more meaningful, active and helped to students for long term memorization of the concepts. The study of Barai (2017) had similar finding that students had positive perception towards using GeoGebra. It was experienced that students in the experimental group had strong motivation, encouragement, engagement and more attentiveness in learning subject matter than the students in control group. The overall findings supported that the use of GeoGebra in teaching mensuration was more effective in school mathematics classroom. Keong, Horani \& Daniel (2005) pointed that using ICT in teaching and learning enhances to make the concepts clear and meaningful in any subject matter. That is why using GeoGebra is the key principle of teaching mathematics for school teacher as stated by Majerek (2014) according to NCTM principles.

\section{Conclusion}

Blending mathematics teaching with ICT, particular with GeoGebra is an important and effective ways for meaningful understanding of mathematical concepts as drawn 
from the findings of this research. The use of GeoGebra in teaching school mathematics increases students' performance in comparison to only use of traditional method of teaching. Use of GeoGebra plays very vital role to make clear concept about 2D and 3D shapes and increase students' curiosity towards mathematics contents. The proper use of ICT does not only increase the students' marks but also motivate them to their study in mathematics. GeoGebra software enhances the creativity and visualization of concept about different shapes. There is no doubt that using Geogebra software enhances clear information about mathematics topic; especially about mensuration and geometry as well as other related concepts. There are many challenges in using GeoGebra software at secondary level and to make clear concept about various shapes. If Curriculum Development Centre (CDC) included the course related to GeoGebra software at school level curriculum, it gives more knowledge and ideas about teaching mathematics. Thus, the use of ICT, particularly GeoGebra is an effective tool to increase achievement; to promote curiosity and creativity; to make clear sense of concepts; and to encourage overall learning of students in mathematics. Finally, the study suggests that school mathematics teachers need to use ICT for effective teaching and learning.

\section{Acknowledgements}

We would like to express our enormous gratitude to the University Grants Commission (UGC) for providing fund to support this research study.

\section{References}

Barai, M. (2017). Perception of students on the use of GeoGebra in Geometry teaching. Unpublished Master's thesis. Tribhuvan University, Nepal

Bozkurt, G. \& Ruthven, K., (2009).Teaching with geogebra: Research systems of mathematics teaching ( ICTMT Report 13). Retrieved from: https://ictmt13.sciencesconf.org/140349/document

Keong, C. C., Horani, S. \& Daniel, J. (2005) A Study on the Use of ICT in Mathematics Teaching. Malayasian Online Journal of Instructional Technology (MOJIT). 2(3), pp. 23-51. Retrieved from: https://www.researchgate.net/publication/228636180

Lamichane, D. R. (2017). Effectiveness of GeoGebra on students' achievement in Geometry.Unpublished Master's thesis. Tribhuvan University, Nepal.

Majerek, D. (2014). Application of GeoGebra for teaching mathematics. Advances in 
Science and Technology Research Journal.8(24), pp. 51-54.

doi:10.12913/22998624/567

Ministry of Education [MOE]. ICT in Master Plan 2013-2017. Kathmandu: Author

Prabha, L. S. \&Shanavas, M. (2014). Implementation of e-learning package for mensuration- a branch of mathematics, Conference Publishing Services, pp. 219-221.dio: 10.1109/WCCCT.2014.37

Rose, W.D. (1904). Aristotle Metaphysics. http://www.documentacatholicaomnia.eu/03d/-384

Sah, S. K. (2017). Teachers' perception towards media in teaching. Unpublished Master's thesis. Tribhuvan University, Nepal

Saha, R. A., Ayub, A. F. M. \& Tarmizi, R. A. (2010). The effects of GeoGebra on mathematics achievement: Enlightening coordinate geometry learning. Procedia Social and Bahavioral Siences,8, 686-693. Retrieved from: https://ac.els-cdn.com/S187707042810022007-main.pdf?_tid=c435e5d3$\mathrm{d} 87 \mathrm{a}-$ 4dec8cacc7d77490948\&acdnat=1536121074_12a99a848378b5eb230e236b8c 665326.pdf

Subedi, A. (2017). Learning resources in mathematics education: Priority and Authenticity. Journal of Academic Research, 1(9), pp. 57-62. 